\title{
NEO-ESCRAVISMO NO BRASIL CONTEMPORÂNEO: CRIME E CASTIGO
}

\author{
NEW SLAVERY IN CONTEMPORARY BRAZIL: \\ CRIME AND PUNISHMENT
}

Por Wilson Ramos Filho*

RESUMO: Considerando-se, a fim de se sobrestarem equívocos, que a dissimilaridade se impõe como referencial na distinção entre o trabalho escravo contemporâneo e o trabalho escravo histórico, o presente artigo embrenha sua discussão por duas correntes tipológicas do trabalho escravo contemporâneo: o rural e o urbano, e, este último, em esforço conceitual, fluindo por duas significativas vertentes: o trabalho escravo prestado sem suporte contratual válido e o trabalho prestado em condições de neo-escravidão com suporte contratual válido, nos termos da legislação vigente. Para tanto, o presente artigo proporá caracterizaremse como práticas criminosas as condutas descritas abstratamente no artigo 149, do Código Penal brasileiro, ensejando inclusive condenação dos delinqüentes à indenização por ato ilícito, no âmbito da Justiça do

* Wilson Ramos Filho, doutor em Direito, é professor catedrático na UNIBRASIL e professor adjunto na UFPR, nas disciplinas de direito sindical e de direito do trabalho, na graduação, no mestrado e no doutorado. Advogado militante em Curitiba, atualmente realiza pesquisa em pós-doutorado na École de Hautes Études en Sciences Sociales, em Paris.
Trabalho, independentemente da aplicação de outras punições que a esfera da jurisdição penal no âmbito criminal imputar.

PALAVRAS-CHAVE: neo-escravidão; neoescravismo; delinqüência patronal; condição análoga à de escravo.

ABSTRACT: In considering that there is no similarity between contemporary slave work and historical slave work, this article intends to discuss two types of contemporary slave work: rural work and urban work, this latter considered from two perspectives such as slave work without valid labor contract and work done in conditions of new-slavery but with valid labor contract according to current labor legislation. Then, this article aims at showing that such working practices can be described as criminal practices according to the criminal legislation, particularly, article 149 of Brazilian Criminal Code so that in the realm of labor law the accused can be considered guilt and be obliged to repair the plaintiff for unlawful act.

KEYWORDS: new slavery; boss delinquency; analogous slave condition. 


\section{INTRODUÇÃO}

Manchetes denunciam ocorrências de "trabalho escravo" com inquietante frequiência, contribuindo para que o Estado brasileiro tutele ações impeditivas e punitivas mediante programas governamentais específicos ${ }^{1}$, seja na agricultura, seja na agroindústria ${ }^{2}$, seja no trabalho urbano ${ }^{3}$. O presente artigo propõe uma análise a respeito da incidência tanto da legislação penal quanto da legislação trabalhista em esfera da exploração do trabalho humano que se identifique como "trabalho escravo contemporâneo".

Do ponto de vista analítico, além do trabalho escravo rural contemporâneo, mais freqüentemente explorado e, por tal razão, noticiado, diferenciem-se duas outras espécies de "trabalho escravo urbano contemporâneo"

1 http://www.oitbrasil.org.br/trabalho_forcado/ brasil/iniciativas/plano_mda_incra.pdf, acessado em 01/09/2008 .

2 http://www1.folha.uol.com.br/folha/dinheiro/ ult91u443329.shtml, acesso em 12/09/2008.

3 "O trabalho escravo urbano é menor se comparado ao do meio rural. A Polícia Federal, as Delegacias Regionais do Trabalho, o Ministério Público do Trabalho e o Ministério Público Federal já agem sobre o problema. Vale lembrar que a escravidão urbana é de outra natureza, com características próprias. Portanto, pede instrumentos específicos para combatê-la - e não adaptações do que está sendo proposto para a zona rural", conforme http:// www.reporterbrasil.org.br/conteudo.php?id=9, acesso em 11/09/2008.

4 "O trabalho escravo urbano é menor se comparado ao do meio rural. A Polícia Federal, as Delegacias Regionais do Trabalho, o Ministério Público do Trabalho e o Ministério Público Federal já agem sobre o problema. Vale lembrar que a escravidão urbana é de outra natureza, com características próprias. Portanto, pede instrumentos específicos para combatê-la - e não adaptações do que está sendo proposto para a zona rural", conforme http:// www.reporterbrasil.org.br/conteudo.php?id=9, acesso em 11/09/2008. a primeira, o trabalho prestado nas cidades em condições análogas à de escravo sem suporte contratual válido, e, a segunda, o trabalho oferecido nas cidades com suporte contratual prestado em situações análogas à de escravos, cuja descrição e tipificação encontram-se no Código Penal, em seu artigo 149, alterado pela Lei n. ${ }^{\circ} 10.803 / 2003$. A essa segunda espécie, prestado nas cidades, com suporte contratual válido, por trabalhadores em situação análoga à de escravos, propõese a denominação "neo-escravidão urbana" ou a denominação de "trabalho urbano prestado em condições de neo-escravidão" (RAMOS FILHO, 2008).

Dentre as duas espécies de trabalho urbano contemporâneo, aquela que explora o trabalhador no âmbito das cidades, sem suporte contratual válido, recebe reprovação mais veemente tanto por parte da doutrina quanto pela jurisdição, eis que muitas vezes tal ocorrência amalgama-se na similaridade como "trabalho escravo rural contemporâneo", ou com o "trabalho escravo histórico", ou seja, com o trabalho escravo, majoritariamente negro, aceito porque inoculado no inconsciente coletivo brasileiro, até 1888 , como modo de trabalho lícito.

Nessa primeira espécie de trabalho em condições análogas à de escravo, para que se permaneça em apenas num exemplo, resta incluído aquele prestado por trabalhadores imigrantes (MENDES, 2003: 68), nas cidades, sem suporte contratual válido. Nessas relações de trabalho pré-capitalistas sonegase ao trabalhador contrato de trabalho válido. As vítimas se sujeitam ao desabrigo do Estado e essa relação se consuma porque os próprios trabalhadores se reconhecem na condição de imigrantes clandestinos; assim, 
tacitamente se curvam ao jugo de tais formas de trabalho, abdicando até mesmo do inarredável, do inalienável direito de ir-e-vir, como freqüentemente ocorre no caso do trabalho rural escravo contemporâneo. Essa espécie será doravante denominada "trabalho escravo prestado por imigrantes", para uma melhor e mais fácil identificação, muito embora existam outros tipos de relação a ela equiparáveis ${ }^{5}$.

Já o trabalho prestado nas cidades, com suporte contratual válido, executado por trabalhadores em situação análoga à de escravos, denominado, a partir deste momento, trabalho urbano em condições de neoescravidão, não encontra melhor amparo, quer em razão de a jurisdição penal deixar de aplicar penas aos empregadores pilhados na conduta tipificada no artigo 149 do CP, quer porque a jurisdição trabalhista não vem condenando, como regra, tais empregadores ao pagamento de indenizações por ato ilícito (submeter empregados a condições de trabalho análogas à de escravos).

Tendo por objetivo secundário alterar essa realidade, pretende este artigo que tal discussão se imiscua em esferas mais amplas, naquelas concernentes à efetividade dos direitos humanos, principalmente os chamados direitos humanos econômicos, sociais e culturais (ABRAMOVICH \& COURTIS, 2002; PISARELLO, 2007) que, quando positivados, denominam-se, também,

5 Certamente existem outras situações de prestação de trabalho remunerado sob subordinação, sem suporte contratual válido, como, por exemplo, aquela associada ao tráfico de pessoas para fins sexuais ou dos "soldados do tráfico de drogas", ou, ainda, pessoas empregadas em casas de jogos, e outros tantos, e que não serão tratados neste artigo. "direitos fundamentais sociais" (SARLET, 2006), dentre os quais se insere o Direito do Trabalho.

Estima-se que, em todo o mundo, 27 milhões de pessoas sujeitem-se ao trabalho escravo $^{6}$, sendo que significativa concentração desse contingente parece incidir no Hemisfério Sul. A América Latina contaria com 1.320.000 pessoas sob tal condição, cabendo 25.000 destes ao Brasil (PIOVESAN, 2006: 149), excluindo-se desse quantitativo os milhares de casos de trabalhadores submetidos à situação de "neo-escravidão urbana".

Tentativas de explicação para a remanescência de tais relações de exploração do trabalho pré-capitalista, que rumorejam no mundo além-fronteiras, também ecoam em justificativas nacionais, nem sempre bemsucedidas, porém.

A literatura especializada brasileira registra parte das explicações atribuindo à inanição do Estado a prática dessa forma de

6 “A Organização das Nações Unidas (ONU) enviará uma missão ao Brasil para avaliar a situação do trabalho escravo no País. A relatora especial das Nações Unidas que lida com as formas contemporâneas de escravidão, Gulnara Shahanian, já indicou ao Itamaraty que pretende realizar a missão até o início do próximo ano [2009]. Em seu relatório que será apresentado amanhã em Genebra, Gulnara alerta que 27 milhões de pessoas no mundo são vítimas de trabalho escravo. "Não há país imune a essa proliferação, especialmente no caso de crianças", afirmou. Segundo ela, muitas são impedidas de ter seu direito básico de nascer livre e ser protegida da escravidão. "Tempos e realidades podem ter mudado, mas a essência da escravidão persiste ", disse a relatora em seu documento. A tentativa de o Brasil lidar com a situação vem sendo indicada pela ONU como um exemplo, principalmente diante das iniciativas tomadas por governos estadual e federal. Mas a ONU alerta que o problema da escravidão no Brasil ainda existe e é grave". Conforme acesso em 22/09/2008 no site http://br.noticias.yahoo. com/s/08092008/25/manchetes-missao-da-onu-avaliartrabalho-escravo-no-brasil.html. 
escravidão, e os argumentos resvalam para a fiscalização/repressão por agentes responsáveis (DRTs, Ministério Público do Trabalho, Justiça do Trabalho, e outros) que, incumbidos constitucionalmente de velar por relações de trabalho dignas, seja no campo, seja nas cidades, dispõem de pessoal em tão ínfima medida que a legitimação de tais direitos jamais se consuma. As "explicações" que se aduzem inculpam o próprio Estado pela ocorrência de trabalho escravo e vertem de fontes ideológicas potencialmente antagônicas: uma vertente de corte nitidamente liberal, ou mesmo, neoliberal, escamoteia a figura do delinqüente (empregador que submete seus empregados a tais condições de trabalho) por detrás da crítica estadofóbica ${ }^{7}$; outra nascente, que se apresenta como "crítica" ou "de esquerda", na ânsia de reivindicar "mais Estado" (mais físcalização, mais intervenção, mais aparelhamento dos órgãos) também empalma os verdadeiros agentes, praticantes do crime, ao focar sua análise na "falta de fiscalização" estatal sobre tais relações de trabalho.

Por outro lado, outra vertente busca explicações para tal remanescência, e responsabiliza a reduzida oferta de empregos que caracterizaria a atual fase de desenvolvimento do capitalismo, principalmente para os setores sociais com baixa qualificação profissional (FORRESTER,

7 Utiliza-se o neologismo estadofóbico para nele incluir tantos quantos atribuem todas as mazelas sociais ao Estado, por exemplo, aqueles que diante da falência de um banco ou de uma companhia aérea 'responsabilizam' o Banco Central ou a Anatel por não haverem atuado antes, preventivamente, para evitar a bancarrota, mas sempre inocentando os gestores de tais empresas e seus acionistas.
1997). Segundo esta última linha de argumentação, para tais trabalhadores melhor ter qualquer trabalho, mesmo que em condições precárias, do que não ter nenhum trabalho (BASTOS, 2006: 368). Muito embora seja verdadeiro que "se o desemprego não existisse os capitalistas o teriam inventado" e a minguada oferta de empregos lograsse justificar a submissão voluntária ao regime econômico fundado na expropriação da maisvalia, tal posicionamento não legitimaria o propósito de induzir-se o empregado à aceitação de condições de trabalho précapitalistas; ou seja, a existência do "exército industrial de reserva" justificaria a exploração capitalista, mas não a pré-capitalista.

Todavia, até mesmo essa afirmação haverá de ser matizada, seja porque no mundo ainda não ocorreu o tal "fim dos empregos" (RIFKIN, 2004), seja porque, no caso brasileiro dos últimos seis anos, a oferta de empregos cresce em taxas significativamente superiores à média mundial. Para tal vertente, portanto, a "explicação" para a existência do trabalho escravo contemporâneo decorreria não da cupidez exacerbada dos delinqüentes ${ }^{8}$ (empregadores), mas das características próprias das vítimas da escravidão (por serem ignorantes e habitantes dos confins, por serem imigrantes, por serem pouco qualificados). Se a primeira corrente atribui ao Estado essa situação que se instala, na segunda responsabiliza as próprias vítimas, e novamente os reais agentes do crime se esfumam num insidioso anonimato.

8 Delinqüência [Do lat. delinquentia.]. Subst. feminino. Ato de delinqüir. Delinqüente [Do lat. delinquente.]. Subst. ou adj. de dois gêneros. Que ou quem delinqüiu. Delinqüir [Do lat. delinquere.]. Verbo intransitivo. Cometer falta, crime, delito. 
Uma terceira forma de se avaliar tal processo atribui responsabilidades a quem por justiça deve responder pela ocorrência, ou seja, o agente da ação criminosa, aquele que pratica o crime, o ator por excelência dessa exploração sob neo-escravidão. Também esta visão descortina duas vertentes: a primeira irriga o regime de neo-escravidão mediante adoção de um "sujeito substitutivo", e a segunda fecunda a produção de algo muito concreto: o lucro antijurídico que se obtém com a certeza da impunidade.

A primeira vertente entorna a "culpa" pelo neo-escravismo sobre o "mercado", sobre a "globalização", sobre a "concorrência internacional" "ou sobre sujeitos substitutivos equivalentes, todos utilizados para mais uma vez escamotear a responsabilidade aos delinqüentes concretamente assim considerados (RAMOS FILHO, 2001). Atribuindo-se a culpa da neo-escravidão a entidades quase metafísicas, quase forças da natureza, o "inimigo" a ser combatido se volatiza, quando não "perdoando" condutas criminosas, ao menos ascendendo estrategicamente a limbos intangíveis. Nessa visão, curiosamente, podem ser incluídos tanto os, digamos, críticos

9 "Deve-se ter em mente que a escravidão contemporânea — ou ao menos o seu boom — é produto lateral da chamada "globalização" da economia. Nas regiões e nos estados brasileiros nos quais a agricultura se insere mais fortemente numa economia de mercado, buscando competitividade junto aos consumidores do país e do exterior, os índices de trabalho escravo tendem a ser maiores: "relações de trabalho arcaicas e desumanas persistem e até são incrementadas em nosso modelo de desenvolvimento", fundado no neoliberalismo econômico, na acumulação de divisas pelo superávit da balança comercial e na livre concorrência [...] Ali, onde a empresa brasileira foi estimulada a se tornar competitiva, é onde agora grassa o trabalho escravo" (FELICIANO, 2004). Para uma crítica arguta do processo de globalização neoliberal, ver PRONER, 2007. nacionalistas (que atribuem mazelas em sua totalidade à globalização, aos mercados, ao neoliberalismo, à concorrência internacional, sempre em prejuízo das empresas nacionais), quanto os que indultam condutas criminosas encravando alegações nas mesmíssimas justificativas: os empregadores pilhados em práticas neo-escravistas estariam simplesmente "tentando sobreviver" nesse "mercado" competitivo. Para esse tipo de visão, portanto, a responsabilidade seria da "globalização", para dizê-lo em uma única palavra, e como ninguém de bom-senso se oporia à globalização, todos, inermes, curvam a cerviz diante das "forças-da-natureza" e tudo o mais se anula, já que nada mais restaria ser feito.

A segunda vertente, pragmática, não utiliza sujeitos substitutivos. Atribui responsabilidade a quem efetivamente pratica condutas descritas abstratamente na lei (art. 149, CP) como criminosas: típicas, antijurídicas, culpáveis e puníveis. E “explica” a conduta criminosa pela conjugação de fatores: cupidez e expectativa de impunidade (ou, no mínimo, de lenidade do Poder Judiciário) por parte dos empregadores neo-escravistas.

O presente artigo decorre desta última racionalidade para propor uma explicação que justifique o paradoxo da coexistência de tais formas de trabalho pré-capitalistas com o mais virtuoso ciclo de desenvolvimento econômico da história de nosso país.

De fato, passados seis anos desde a posse do presidente Lula, nunca os índices de desenvolvimento humano, de distribuição de renda $^{10}$, de escolaridade, de baixa mortalidade

${ }^{10}$ Conforme sitio http://www1.folha.uol.com.br/ folha/dinheiro/ult91u447621.shtml, acessado em 22/09/2008. 
infantil, de baixo desemprego ${ }^{11}$ foram tão alvissareiros, muitos deles associados ao significativo aumento do $\mathrm{PIB}^{12}$, o que rende expressivos níveis de aprovação às políticas governamentais bem-sucedidas ${ }^{13}$, em

${ }^{11}$ Desemprego cai para 7,6\%, segunda menor taxa da série: "O desemprego caiu mais que o esperado em agosto e foi o segundo menor da série histórica do IBGE (Instituto Brasileiro de Geografia e Estatística), iniciada em 2002. A taxa ficou em 7,6\% em agosto, inferior aos $8,1 \%$ registrados em julho e aos $9,5 \%$ de agosto do ano passado. Analistas consultados pela agência de notícias Reuters estimavam que a taxa ficaria em $8 \%$. O desemprego foi o menor para meses de agosto e o segundo menor de toda a série, atrás apenas de dezembro do ano passado (7,4\%). No último mês do ano, o desemprego tende a ser sempre menor. Em números absolutos, a população ocupada já abrange 21,8 milhões de trabalhadores, número $0,7 \%$ maior o que o verificado em julho e 3,7\% superior ao de agosto do ano passado. Entre eles, 9,6 milhões têm carteira assinada no setor privado, alta de $5,8 \%$ sobre um ano atrás. A população desocupada é de 1,8 milhão, o que representa uma queda de $6,1 \%$ em relação a julho e $19,2 \%$ ante agosto do ano passado. A renda dos trabalhadores também apresentou aumento, segundo o IBGE. O rendimento médio real atingiu $\mathrm{R} \$ 1.253,70$, alta de $2,1 \%$ em relação a julho e 5,7\% sobre um ano atrás", conforme http:// economia.uol.com.br/ultnot/2008/09/25/ult4294u1679. jhtm, acessado em 24/09/2008 e também veja-se o seguinte sitio acessado em 23/08/2008: http://noticias. uol.com.br/economia/ultnot/efe/2007/08/23/ ult1767u101001.jhtm.

${ }^{12}$ O Produto Interno Bruto (PIB) do Brasil cresceu $6 \%$ no primeiro semestre deste ano em comparação com igual intervalo do ano passado, segundo o IBGE (Instituto Brasileiro de Geografia e Estatística). Na primeira metade de 2007, a alta havia sido de 4,9\% sobre um ano antes. Nos quatro trimestres encerrados em julho, o crescimento também foi de $6 \%$, conforme http://economia.uol.com.br/ultnot/2008/09/10/ ult4294u1648.jhtm, consultado em 10/09/2008.

13 DATAFOLHA: "Entre a pesquisa realizada em março e agora, houve um salto a favor de Lula de 14 pontos percentuais entre os brasileiros mais ricos. Hoje, $57 \%$ dos que vivem em famílias que ganham $\mathrm{R} \$ 4.150,00$ ou mais por mês aprovam seu governo. Lula também conquistou pela primeira vez a maioria no Sudeste: $57 \%$ o aprovam, dez pontos acima da última pesquisa. Há substituição àquelas, de corte neoliberal, adotadas nos governos anteriores, a partir da redemocratização do país.

Sustenta-se que remanescem resquícios de escravo, e, pior, de trabalho que, pela precariedade das condições em que ocorrem, nivela-se à condição análoga à de escravo, não por razões decorrentes da escassez da oferta de empregos, nem por "culpa" dos próprios trabalhadores, nem por ausência de fiscalização por parte do Estado, nem pela utilização de um culpado substitutivo, mas em decorrência da cobiça e da expectativa de impunidade que move os empregadores neo-escravistas.

alguns anos Lula também só tinha a maioria ao seu lado em regiões do interior. Agora, 57\% dos moradores das regiões metropolitanas o aprovam. Por fim, Lula também venceu a barreira entre os mais escolarizados. Em março, $47 \%$ dos brasileiros com curso superior consideravam seu governo ótimo/bom. Agora, são 55\%. Os resultados da pesquisa coincidem com a divulgação, anteontem, de um crescimento do PIB (Produto Interno Bruto) de 6\% no primeiro semestre do ano. Nesse bom resultado, houve uma significativa participação do consumo das famílias brasileiras, que cresceu $6,7 \%$ (a $19^{\mathrm{a}}$ alta seguida) apoiado em aumentos da renda [...] Na pesquisa, o Datafolha ouviu 2.981 pessoas maiores de 16 anos em 212 municípios do país entre os dias 8 e 11 de setembro. A margem de erro é de dois pontos, para mais ou menos. Além de ter ultrapassado barreiras, o levantamento revela que Lula também ampliou de maneira significativa o reforço à sua popularidade entre os que já o apoiavam. No Nordeste, por exemplo, região que sempre deu os melhores índices de popularidade a Lula, sua avaliação subiu mais sete pontos. Hoje, 3 entre cada 4 nordestinos o apóiam. Houve ainda um salto de oito pontos percentuais a favor do presidente entre os mais pobres, com renda familiar até cinco salários mínimos. Atualmente, $65 \%$ desses brasileiros avaliam Lula positivamente", conforme http://www1.folha.uol.com. br/folha/brasil/ult96u444114.shtml, acessado em 12/09/08, dado confirmado pela pesquisa CNT/Sensus: "Governo do presidente Lula atinge melhor avaliação desde 1998", conforme sitio http://www1.folha.uol.com. br/folha/brasil/ult96u447506.shtml, acessado em 23/09/2008. 
Para tanto, traça-se um panorama da legislação em vigor, analisam-se os destaques dessas normas, a fim de se propor que se considerem práticas criminosas, de delinqüência patronal, ${ }^{14}$ as condutas descritas abstratamente pelo artigo 149, $\mathrm{CP}$, ensejando, inclusive, condenação dos delinqüentes a indenização por ato ilícito, no âmbito da Justiça do Trabalho, independentemente da aplicação de punições que a jurisdição criminal impuser.

\section{UMA TIPIFICAÇÃO ATUAL DO TRABALHO DESENVOLVIDO SOB CONDIÇÕES ANÁLOGAS ÀS ENFRENTADAS PELO ESCRAVO NEGRO}

Os tratados, os pactos, as declarações e as convenções internacionais de proteção dos direitos humanos enfatizam a afirmação de que o trabalho escravo, pelas condições degradantes em que se desenvolve, consistiria em grave forma de violação dos direitos humanos ${ }^{15}$. No mesmo teor, as constituições

${ }^{14}$ Como tanto empregados como empregadores podem ser sujeitos ativos de crimes dentro do liame empregatício é que se optou por designar por "delinqüência patronal" os crimes praticados por empregadores que tenham como vítimas seus empregados no âmbito de uma relação de emprego.

15 "Sob o prisma da concepção contemporânea de direito humanos e da indivisibilidade e interdependência destes direitos, conclui-se que o trabalho escravo constitui flagrante violação aos direitos humanos, sendo, ao mesmo tempo, causa e resultado de grave padrão de violação de direitos. Vale dizer, o trabalho escravo se manifesta quando direitos fundamentais são violados, como o direito a condições justas de um trabalho que seja livremente escolhido e aceito, o direito à educação e o direito à uma vida digna"[...]"À luz da universalidade dos direitos humanos, o trabalho escravo viola sobretudo a idéia fundamente dos direitos, baseada na dignidade dos países democráticos repudiam veementemente tais práticas.

No direito brasileiro consagra-se o repúdio ao trabalho escravo desde a Constituição (art. $5^{\circ}$, incisos III, XIII, XV, XLVII e LXVII) até a atual redação dos artigos 149, 197, 203, 206 e 207, do Código Penal, além de todas as normas internacionais ratificadas e internalizadas.

No caso da legislação infraconstitucional brasileira, o antigo teor do artigo 149 foi alterado pela Lei n. ${ }^{\circ} 10.803 / 2003$, sancionada pelo atual presidente da República ao final de seu primeiro ano de mandato (12/12/2003), a fim de atualizar a legislação com base tanto na Constituição Federal de 1988 quanto nas normas internacionais aplicáveis.

A redação anterior do artigo 149 dispunha como crime "Reduzir alguém à condição análoga à de escravo", sem definir o que caracterizaria tal condição.

O preceito dispunha-se em redação que escancarava ampla interpretação, cabendo ao intérprete definir o que considerar como “condição análoga à de escravo", num dilema a descortinar juízos entre aspectos positivos e negativos. Como aspecto positivo, mencione-se que a redação aberta permite maior flexibilidade hermenêutica para a caracterização do crime, "desde que a sua exegese e aplicação caibam a bons juízes $e$ promotores" (FELICIANO, 2004: 07). Mas, ao tempo de sua vigência, também houve quem criticasse tal redação exatamente por não subsidiar os julgadores com critérios objetivos

\footnotetext{
humana, como um valor intrínseco à condição humana. (...) O trabalho escravo surge como a negação absoluta do valor da dignidade humana, da autonomia e da liberdade ao converter pessoas em coisas e objetos" (PIOVESAN, 2006:163/4).
} 
para uma precisa tipificação, além, óbvio, de não caracterizar como crime a apropriação do trabalho escravo propriamente dito, mas apenas o trabalho prestado em condições análogas à de escravo (MELO, 2000: 51).

A Lei n. ${ }^{\circ} 10.803 / 2003$ modificou a situação, conferindo ao artigo 149 uma nova redação:

Redução a condição análoga à de escravo

Art. 149. Reduzir alguém a condição análoga à de escravo, quer submetendo-o a trabalhos forçados ou a jornada exaustiva, quer sujeitando-o a condições degradantes de trabalho, quer restringindo, por qualquer meio, sua locomoção em razão de divida contraída com o empregador ou preposto:

Pena - reclusão, de dois a oito anos, e multa, além da pena correspondente à violência.

$\S 1^{\circ}$ Nas mesmas penas incorre quem:

I - cerceia o uso de qualquer meio de transporte por parte do trabalhador, com o fim de retê-lo no local de trabalho;

II - mantém vigilância ostensiva no local de trabalho ou se apodera de documentos ou objetos pessoais do trabalhador, com o fim de retê-lo no local de trabalho.

$\S 2^{\circ}$ A pena é aumentada de metade, se o crime é cometido:

I - contra criança ou adolescente;

II-pormotivo de preconceito de raça, cor, etnia, religião ou origem" (destaque deste autor).

Constata-se que a nova proposição preocupou-se em adotar um tipo penal fechado em substituição à opção anterior, tipo penal aberto.

Desde então - embora tal medida não tenha ainda ensejado grandes repercussões na jurisdição trabalhista - o entendimento concernente à expressão condição análoga à de escravo restringiu-se a quatro hipóteses: (i) sujeição alheia a trabalhos forçados; (ii) sujeição alheia à jornada exaustiva; (iii) sujeição alheia a condições degradantes de trabalho; (iv) restrição, por qualquer meio, da locomoção alheia em razão de dívida contraída com o empregador ou preposto.

Sendo assim, em não se verificando nenhum dos quatros modos, não se logra tipificação do crime (FELICIANO, 2004: 11). A contrario sensu, verificada qualquer uma das quatro hipóteses, ainda que separadamente, consuma-se a caracterização do crime, tipificado como tal pela legislação brasileira, ensejando a repressão penal e a reparação civil, no âmbito da Justiça do Trabalho. Esta interpretação da Lei n. ${ }^{\circ}$ 10.803/2003, precisamente, impõe-se como a idéia-força que moveu o autor à redação do presente artigo.

\section{TRABALHO PRESTADO SOB SITUAÇÃO DE NEO-ESCRAVIDÃO E A RESTRIÇÃO À LIBERDADE DE LOCOMOÇÃO}

A principal dificuldade de se admitirem certas condutas de empregadores tipificandoas como crime talvez decorra do condicionamento que a todos move quando sobre sua memória se calca o peso simbólico da palavra escravidão.

Desde cedo, as instituições norteiam culturalmente o brasileiro para o repúdio ao trabalho escravo, sempre exemplificando com a escravidão negra admitida juridicamente até 1888 no país. A imagem que se delineia associa tal prática ao trabalho pesado, usurpado ao látego da chibata, em subumanas condições, com restrição à liberdade de ir-evir. Em ocorrências de fuga, os escravos eram caçados como animais e submetidos a toda 
sorte de torturas e humilhações. Esses fatos históricos maculam as lembranças do povo envergonhado de figurar como um dos últimos países a abolir a escravatura, o que ocorreu apenas quando tal situação mostrouse desinteressante ao desenvolvimento das forças produtivas e do capitalismo, que possibilitou a "invenção do emprego" (MÉDA, 2004: 44).

Desde então, imputar a alguém conduta escravista tem peso simbólico e gravidade significativa. Isso talvez justifique a opção do legislador em utilizar a expressão “condição análoga à de escravo” à expressão contida nos textos internacionais, até porque juridicamente "trabalho escravo" não existe desde a abolição (BRITO FILHO, 2006: 130), embora a vida real demonstre diuturnamente o contrário.

Talvez nesse entendimento se instale o cadinho da resistência a que doutrinadores e magistrados recorrem para preconizar a aplicação da lei penal e cujas conseqüências repercutem em outros ramos do direito, quando confrontados com situações descritas abstratamente pela lei, como prática criminosa.

De toda sorte, independentemente de ser ou não reconhecida "juridicamente" a escravidão, apesar das resistências de alguns, fato é que, depois da Lei n. ${ }^{\circ}$ 10.803/2003, considera-se crime:

1. sujeição alheia a trabalhos forçados;

2. sujeição alheia à jornada exaustiva;

3. sujeição alheia a condições degradantes de trabalho; ou

4. restrição, por qualquer meio, da locomoção alheia em razão de dívida contraída com o empregador ou preposto.
Para não confundir tais condutas criminosas com a "escravidão histórica", utiliza-se a expressão "condição análoga à de escravo" que, mais freqüente nas áreas rurais, remanesce também nas cidades.

Como mencionado, o trabalho escravo contemporâneo exercita dois gêneros: o rural e o urbano, este, urbano contemporâneo, abriga duas espécies principais: a primeira, do trabalho escravo prestado por imigrantes ilegais, nas cidades, em situação particularmente similar àquela dos trabalhadores encontrados em condições análogas à de escravos nas zonas rurais e, a segunda, do trabalho prestado pelas vítimas das condutas tipificadas pelo artigo 149, caput, do CP, pelas vítimas da "neoescravidão", mais especificamente aquelas tipificadas nos tópicos "b" e "c" (já que as condutas mencionadas em "a" e em "d", supra, são comuns a outros gêneros e espécies da escravidão contemporânea).

Estabelecido tal acordo semântico, registre-se que, em relação a esta última espécie de trabalho (em condições análogas à de escravo), não se exige restrição à liberdade de locomoção para que se consume tal caracterização; basta que o empregador submeta o empregado a "jornadas exaustivas" ou que sujeite seu empregado a "condições degradantes de trabalho" para que a imputação do crime se materialize.

Em outros tipos de escravidão contemporânea, que não serão abordados neste artigo, geralmente se restringe a liberdade de ir-e-vir. Com efeito, tanto na escravidão rural quanto na primeira espécie de escravidão urbana contemporânea, relativas ao trabalho escravo prestado pelos imigrantes ilegais, a liberdade de locomoção 
se faz sentir como traço característico (MENDES, 2003: 68).

Tal situação não ocorre em relação aos trabalhadores submetidos à neo-escravidão urbana: nestes casos não se estabelece restrição ao direito de ir-e-vir, mas "tãosomente" se impõe trabalho degradante ou trabalho prestado em jornadas exaustivas, até porque, em tempos de discussão sobre a efetividade dos direitos sociais e, em especial, dos direitos dos trabalhadores, não se admitiria para caracterização do crime exigirse como condição o cerceamento do direito à liberdade de locomoção. Como se depreende da simples leitura do artigo 149 modificado, a privação ou a restrição à liberdade, segundo a nova disciplina legal, não contribui como condição necessária para a tipificação da conduta criminosa.

Sendo assim, caminhando para a conclusão desta parte, resta abordar o entendimento da expressão "trabalho degradante" e considerações a respeito do que se entende como "jornada exaustiva". Inverte-se, portanto, a ordem contida no artigo 149, CP, por considerar que o conceito de "jornada exaustiva", apesar de sua especificidade, já estaria contido na expressão "trabalho degradante".

\section{IV.TRABALHO DEGRADANTE E EXIGÊNCIA DE JORNADAS DE TRABALHO EXAUSTIVAS: TIPIFICÁVEIS COMO PRÁTICAS NEO-ESCRAVISTAS}

A amplitude que se queira conferir à expressão "trabalho degradante" depende de valorações muitas vezes subjetivas. Para se delimitarem exageros, e no encalço de um conteúdo mínimo para tal caracterização, apela-se a uma referência externa que seja amplamente aceitável.

De fato, devem-se evitar radicalismos nas considerações de que a apropriação da mais-valia, ela mesma, já se denunciaria "abusiva" ou "degradante"; ou, no outro extremo, que se tolerasse toda sorte de abusos patronais na equivocada suposição de que tais empregadores exerceriam uma "função social", já que "bem ou mal" estariam "dando" empregos.

O critério externo a atuar como pêndulo nessa avaliação sobre "trabalho degradante" deve ser obtido pela conjugação de dois fatores: um factual, outro axiológico. $\mathrm{O}$ factual decorre da adequação de uma relação de trabalho concreta à disciplina legal incidente sobre tal relação, ou seja, o cumprimento pelo empregador dos direitos mínimos fixados pela legislação; o axiológico decorre do respeito ao conceito de dignidade humana, entendida como a conjunção dos valores de liberdade e de igualdade e vida (HERRERA FLORES, 2008: 129).

Mas, novamente surgem questionamentos oscilando na linha tênue das ponderações: que parâmetros seguir, em exata medida, para se "tolerar" o descumprimento de direitos? Em que determinações ancorar limites, os quais, uma vez ultrapassados, denunciariam o empregador pela exploração do trabalho em situação "degradante" por ferir a "dignidade humana" do trabalhador?

Um critério possível atrelaria, por antonímia, o conjunto de direitos mínimos, sem o qual o trabalho se condenaria degradante, ao que se poderia considerar um "trabalho decente" ${ }^{16}$, socorrendo-se de

${ }^{16}$ Para a Organização Internacional do Trabalho, "Trabalho Decente é um trabalho produtivo e 
condições internacionalmente estabelecidas no Pacto Internacional dos Direitos Econômicos, Sociais e Culturais, da Organização das Nações Unidas, e também nas Convenções Fundamentais da Organização Internacional do Trabalho. Considerando-os, os direitos mínimos seguintes se imporiam: a - condições que permitam ao trabalhador e a sua família subsistir; b - liberdade de escolha do trabalho; c - igualdade de oportunidades para e no exercício do trabalho; $\mathrm{d}$ - direito de exercer o trabalho em condições que lhe preservem a saúde; e - direito a uma justa remuneração; f - direito a justas condições de trabalho (como limitação da jornada e períodos de repouso); $\mathrm{g}$ - proibição do trabalho infantil; $\mathrm{h}$ - liberdade sindical; i - proteção contra o desemprego e outros riscos sociais $^{17}$. A negação desse conjunto

adequadamente remunerado, exercido em condições de liberdade, eqüidade, e segurança, sem quaisquer formas de discriminação, e capaz de garantir uma vida digna a todas as pessoas que vivem de seu trabalho. Os quatro eixos centrais da Agenda do Trabalho Decente são a criação de emprego de qualidade para homens $e$ mulheres, a extensão da proteção social, a promoção $e$ fortalecimento do diálogo social e o respeito aos princípios e direitos fundamentais no trabalho, expressos na Declaração dos Direitos e Princípios Fundamentais no Trabalho da OIT, adotada em 1998: 1- Liberdade de associação e de organização sindical e reconhecimento efetivo do direito de negociação coletiva (Convenções 87 e 98); 2- Eliminação de todas as formas de trabalho forçado ou obrigatório (Convenções 29 e 105); 3Abolição efetiva do trabalho infantil (Convenções 138 e 182); 4- Eliminação da discriminação em matéria de emprego e ocupação (Convenções 100 e 111)" (Fonte: http://www.oitbrasil.org.br/trab_decente_2.php; acesso em 11/02/2008).

${ }^{17}$ Essa é a posição de José Cláudio Monteiro de BRITO FILHO, para quem "Trabalho decente, então, (...) é um conjunto mínimo de direito do trabalhador que corresponde: à existência de trabalho; à liberdade de trabalho; à igualdade no trabalho; ao trabalho com condições justas, incluindo a remuneração, e a preservação de sua saúde e segurança; a proibição do trabalho infantil; à liberdade sindical; a à proteção contra os riscos sociais" (BRITO FILHO,: 128). mínimo equivaleria à negação dos direitos humanos ao trabalhador e atuaria contra a dignidade da pessoa humana, sendo que a “condição degradante" restringiria sua abrangência para péssimas condições de trabalho e de remuneração. Para esta perspectiva, quando não se assegurarem garantias mínimas ao trabalhador, instala-se uma situação de trabalho análogo ao de escravo. A dificuldade, óbvia, reside na referência a textos internacionais e não a diplomas legais internos, tornando mais complexa a hermenêutica, dificultando, portanto, sua aplicabilidade.

Perscrutando critérios mais adequados, tenta-se extrair diferenciação mediante dois conceitos também à primeira vista semelhantes: condições degradantes de trabalho/trabalho executado em condições degradantes que não se confundem com a noção do trabalho degradante em si mesmo. Segundo essa linha de raciocínio, enquanto as condições degradantes de trabalho são absolutamente incompatíveis não apenas com a proteção nacional, mas também com os ditames expressos no Direito Internacional do Trabalho e, ainda, com a legislação penal brasileira, o trabalho degradante, em si, seria reconhecido pelo Direito do Trabalho. O trabalho em condições degradantes se definiria pela relação entre o trabalhador e os meios de prestação do trabalho; o trabalho degradante pelo tipo de atividade realizada. Enfim, nas condições degradantes de trabalho, o termo degradante destacaria as condições; no trabalho degradante, o termo trabalho sobressairia. Nesse sentido, o Direito do Trabalho reconheceria a legalidade do trabalho degradante. Assim, com a idéia de compensação financeira aos riscos à saúde 
do trabalhador, o direito do trabalho prevê a devida remuneração com adicionais de insalubridade ou de periculosidade, a fim de compensar, também no plano econômico, a maior cota de sacrifício ou de risco a que se submete o trabalhador para entregar sua prestação laboral (JARDIM, 2008).

Adotando-se tal linha de argumentação, o trabalho em condições degradantes (art. 149, CP) não se conceituaria segundo sua antinomia em face do conceito de "trabalho decente", mas por diferenciação daquilo que seria tolerado pela legislação capitalista do trabalho. $\mathrm{O}$ direito do trabalho vigente, em sua ambivalência, na exata medida em que "garante" aos trabalhadores o "direito" à percepção de adicionais por trabalho prestado em condições de risco à saúde (insalubridade) ou à vida (periculosidade), assegura aos empregadores o "direito" de exigir trabalho em tais condições de risco, desde que receba pagamento por esse trabalho adicional (desde que se paguem corretamente os adicionais referidos ${ }^{18}$ ).

Sendo assim, "condições degradantes" não se identificariam com situações em que os empregadores ignoram o permissivo legal para colocar em risco a saúde ou a vida do empregado (pagando-lhe o adicional respectivo), mas com aquelas em que a legislação autorizadora da "compra" de tais direitos (à saúde ou à vida ${ }^{19}$ ) tenha sido

18 "Os adicionais consistem em parcelas contraprestativas suplementares ao empregado em virtude do exercício do trabalho em circunstâncias tipificadas mais gravosas." (DELGADO, 2006: 714)

19 "enquanto, na insalubridade, o agente agressor mina incessantemente a saúde do trabalhador, na periculosidade há exposição a um risco que, eventualmente, pode ocasionar em grave sinistro." (SÜSSEKIND, 2000: 925) desrespeitada. Dito de outro modo: se o empregador pagou o adicional (seja de insalubridade, seja de periculosidade), o trabalho seria degradante, mas a legislação protetiva ao empregador teria sido cumprida. De outra parte, se o empregador (qualquer que tenha sido sua fundamentação ou motivação para agir desse modo) deixou de aproveitar da faculdade que a legislação trabalhista lhe assegura, consuma-se uma conduta tipificada como crime: a de submeter empregado a "condições degradantes de trabalho".

O crime, portanto, configura-se inapelavelmente nas situações em que o empregador (delinqüente) submeter empregado (vítima) a condições degradantes de trabalho, sem remuneração suplementar, conforme exigido pela legislação trabalhista.

A contrario sensu, caso o empregador submeta o empregado a condições degradantes de trabalho em troca do adicional de pagamento por tal condição de trabalho (remuneração suplementar por meio de adicionais, seja de insalubridade, seja de periculosidade) em verdade não se tipifica o fato descrito abstratamente no artigo 149 como crime (submeter outrem a condições degradantes de trabalho), mas "apenas" de trabalho degradante em si, admitido pela legislação protetiva, desde que cumprido o pagamento dos adicionais respectivos.

Dito de outro modo, (i) trabalho degradante não é crime; (ii) desde que o empregador pague os adicionais suplementares previstos na legislação trabalhista, o trabalho degradante é, inclusive, legitimado pela legislação trabalhista; (iii) crime é submeter uma pessoa a trabalho degradante sem o pagamento dos adicionais respectivos. Considerando-se correto o raciocínio acima, estaríamos diante 
de uma situação em que (iv) o crime incidiria no descumprimento da legislação trabalhista e (v) o pagamento dos adicionais devidos atuariam como condição excludente em relação à culpabilidade, ou seja, não se tipificaria como crime tal prática.

Desnecessário afirmar que o trabalho continuaria a ser prestado de forma degradante, mas não se consumaria o crime, porque cumprida a legislação trabalhista.

Imagine-se a quantidade de penalistas que se apressariam a defender a possibilidade de "extinção da punibilidade" (alguns até ousariam defender "extinção da culpabilidade") em caso de pagamento, mesmo a destempo, a posteriori, dos referidos adicionais. Alguns, lembrando que a relação de trabalho se estabelece com a empresa e não com a pessoa física do empregador ou de seus prepostos, alegariam "crime impunível”, pois "pessoa jurídica não poderia cometer crime, nem ser criminalmente condenada". Outros, ainda, advogariam que o crime só restaria caracterizado se o empregador fosse notificado previamente da necessidade de pagamento depois do transito em julgado da sentença de liquidação, e, ainda assim, deixasse de realizá-lo. Outros, abolicionistas, se refugiariam na contramão das ciências penais, nas quais cada vez mais se fala em “direito penal mínimo". Por fim, haveria os cínicos a alegar de que faltariam cadeias no país "se essa lei pegasse". Tudo para "se evitar o pior": tipificar como crime as condutas patronais.

Alguém poderia argumentar que os mesmos empregadores, quando sonegam impostos, cometem crimes (sujeitando-se aos rigores da lei penal), e que a mesma racionalidade deveria ser aplicável aos empregadores que sonegassem direitos trabalhistas. Mas, convenha-se, esse tipo de raciocínio se dilataria para além da esfera da racionalidade ambivalente do direito do trabalho, este ramo do direito que legitima a apropriação da mais-valia, ratifica o poder diretivo e punitivo dos empregadores, regula a compra e a venda da força de trabalho no interesse dos empregadores, embora, para tanto, assegure alguns direitos e garantias para os empregados, daí porque se diz que é um ramo do direito ambivalente.

A questão se mostra mais complexa, caso se busque ampliar o conceito de "condições degradantes de trabalho", para incluir, nesse mesmo conceito, todas as demais questões relacionadas com o meio ambiente do trabalho (BELISARIO, 2006: 116; PRUDENTE, 2006: 62), ou para se considerar condição degradante uma relação de trabalho em que se violam direitos trabalhistas fixados na Constituição (NEGRISOLI, 2008) ou na lei. De fato, seguindo tal raciocínio, se a legislação brasileira estabelece o mínimo a ser respeitado, esse conjunto mínimo de direitos alicerça o que entende por um trabalho decente, e, como tal, deve chancelar presença em toda relação de trabalho que se contratar, sem exceções.

Se trabalho decente se propõe como aquele prestado a empregador que respeita no mínimo as garantias e os direitos assegurados pela legislação, a relação de trabalho que, ultrapassando tal limite, resvale para o desrespeito a esse mínimo, em justa ponderação, denuncia-se como trabalho prestado em condições degradantes.

Diante de um conceito tão amplo, teme-se que se fragilize essa inquebrantável aspiração por uma eficácia da lei, com a responsabilização dos empregadores que submetem empregados 
a condições degradantes. Se já se vislumbram dificuldades para se identificarem juízes dispostos a aplicar o artigo 149 do CP em casos "escabrosos" de empregadores pilhados na submissão de empregados a condições análogas à de escravos, no campo ou nas cidades, como a utilização de imigrantes ilegais, caso se confira conceito tão elástico à acepção de "trabalho degradante" prestado em condições análogas à de escravo, talvez a dificuldade em se conseguir a punição dos delinqüientes reste ampliada.

O eventual leitor deste artigo poderá se questionar se caberia autocensura hermenêutica tamanha apenas em busca de uma maior efetividade do dispositivo penal modificado há mais de cinco anos ainda sem grande utilização pela jurisprudência.

Antes de se propor uma solução para o dilema, discute-se a sujeição alheia à jornada exaustiva, como elemento configurador da prática de crime de submissão à condição análoga à de escravo (art. 149, caput, CP).

A Constituição Federal brasileira prevê expressamente que a jornada diária estendase de, no máximo, por oito horas, e a semanal, por quarenta e quatro horas. Ao labor excedente à jornada indicada, a Constituição determina remuneração com, no mínimo, cinquienta por cento de acréscimo. Alegislação infraconstitucional ${ }^{20}$ determina que, em qualquer hipótese, a jornada não exceda ao período de duas horas extras por dia.

Pois bem: o que deve ser considerado como "jornada exaustiva" para caracterização

${ }^{20}$ CLT: “art. 59. A duração normal do trabalho poderá ser acrescida de horas suplementares, em número não excedente de duas, mediante acordo escrito entre empregador e empregado, ou mediante convenção coletiva de trabalho". da prática do crime de submeter outrem à condição análoga à de escravo?

Perseguindo a mesma linha de raciocínio que se adotou para a caracterização das "condições degradantes de trabalho", constata-se que a legislação "legaliza" a prestação de horas para além da carga horária diária máxima, ao estipular que se remunere tal carga horária como "horas extras", ou seja, com adicional de $50 \%$. Sendo assim, o direito do trabalho autoriza o empregador a exigir do empregado horas de trabalho além do limite constitucional de oito horas diárias, cumpridas dadas condições, irrelevantes na presente linha de argumentação.

O tipo penal alude a jornadas exaustivas. Obviamente tal qualificação deve adequar-se à forma que cada trabalho assume, pois, em um trabalho mais intenso, mais rapidamente se atinge a exaustão, enquanto em um trabalho meramente contemplativo pode prolongar-se por muito mais tempo antes que condições de esgotamento equivalentes se instalem. Por essa razão, a legislação prevê intervalos intrajornadas mais freqüentes naqueles. Mas, independentemente de tais ponderações, na busca de um critério objetivo para tal caracterização, seria possível identificar como jornada exaustiva (qualquer que seja a atividade) aquela exigida, regularmente, do trabalhador, para além da décima hora em uma mesma jornada diária; ou seja, para todo trabalho a décima hora, em um mesmo dia, se imporia como o limite quantitativo.

Note-se que o caput do artigo 149 menciona três situações que caracterizariam o trabalho em condições análogas à de escravo, sendo a primeira delas a submissão a trabalho forçado ou a jornadas exaustivas, 
e exatamente nesse contexto que se deve perquirir a melhor hermenêutica. Para o legislador, essa primeira forma de trabalho em condições análogas à de escravo consiste não apenas naquela descrita internacionalmente como "trabalho forçado", muitas vezes associado à restrição à liberdade de locomoção, mas também naquele prestado em relações em que o empregador exige do empregado trabalho em quantidade (máximo de dez horas diárias) ou em intensidade superiores às forças humanas, remetendo a um critério qualitativo para mais adequada configuração.

A questão adquire relevância quando se consideram as importantes alterações na maneira de se gerirem as empresas, experimentadas em nosso novo, e precário, mundo do trabalho (ALVES, 2000), identificadoras de um novo espírito do capitalismo (BOLTANSKI \& CHIAPELO, 2002) no qual a intensidade do trabalho resta potencializada para ampliação crescente das margens de lucro.

Sendo assim, independentemente de o empregador remunerar as horas extras corretamente, sempre que exigir do empregado, com habitualidade, horas de trabalho que ultrapassem o limite máximo de dez horas diárias, uma situação fática de exigência de jornadas exaustivas se consuma ${ }^{21}$.

${ }^{21}$ Esse limite pode ser menor, dependendo do contexto, a critério da Jurisdição, dependendo da complexidade da natureza do trabalho prestado, como mencionado. Da mesma forma, se estará diante de trabalho prestado em jornadas excessivas sempre que o empregador exigir do empregado trabalho em intensidade superior às suas forças, dependendo das condições fáticas, muitas das quais são pressentidas dado o enorme número de ações que tramitam na Justiça do Trabalho na quais se discutem temas correlatos a assédio moral ou acosso psíquico (SIMM, 2008).
Portanto, os termos do o artigo $7^{\circ}$, XIII, da CF/88 e o artigo 149 do Código Penal: (i) quando a jornada diária superar os limites constitucionais deverá haver o pagamento das horas extras (com a ressalva das hipóteses de compensação e das atividades não sujeitos a limite de jornada); (ii) caso o empregador submeta, com habitualidade, um empregado a jornadas superiores ao limite legal (dez horas, artigo 59, CLT) estará submetendo-o à condição análoga à de escravo por exigir-lhe "jornadas exaustivas", ainda que remunere tais horas suplementares; (iii) se o empregador exigir trabalho suplementar e negar-se a remunerar tais atividades executadas em horas extras ${ }^{22}$, o trabalho em condição análoga à de escravo se consuma, não mais por excesso de jornada, mas por submeter o empregado a condições de trabalho degradante, qual seja, o trabalho sem remuneração. Aqui a situação seria similar àquela em que o empregador deixa de pagar o adicional de periculosidade: a condição de trabalho degradante decorre do descumprimento da legislação trabalhista.

Mas se assim é, se desde a alteração na redação do artigo 149, do CP, muitas violações de direitos dos trabalhadores foram identificadas pela Justiça do Trabalho, demandas individuais já ensejariam remessa de cópias dos autos ao Ministério Público para fins de análise e eventual início de ações penais cabíveis.

${ }^{22}$ Ou que deixe de se utilizar de uma das inúmeras possibilidades que o Direito do Trabalho, ambivalente, propicia às empresas para que se eximam de pagar as horas extraordinárias aos empregados (banco de horas, compensação, prorrogação, jornadas flexíveis com chancela sindical, etc.) . 
Retorna-se, desta forma, ao dilema: devese advogar a ampliação das hipóteses a serem consideradas como de "condições degradantes de trabalho" e de "condições de trabalho em jornadas excessivas" como caracterizadoras de "trabalho em condições análogas à de escravo", mesmo correndo o risco de se banalizar tal discussão, ou, ao contrário, em homenagem a uma maior efetividade (e maiores possibilidades de punição, portanto), deve uma autocensura restringir as hipóteses que seriam consideradas como "condição degradante" ou como "jornada excessiva"?

Este é o tema tratado no derradeiro tópico deste artigo.

\section{CRIME E CASTIGO}

Muito embora se louvem os esforços de corajosos agentes de diversas instituições públicas (fundamentalmente Ministério Público do Trabalho, Ministério do Trabalho, e muitos Juízes do Trabalho) e privadas (ONGs, sindicatos e movimentos sociais, como ANAMATRA), tendentes ao banimento do trabalho escravo contemporâneo, tais manifestações se comprovam insuficientes se desacompanhadas de punições aos empregadores que se beneficiam dessas relações de trabalho pré-capitalistas.

Contudo, se já cabe ressentimento pelo fato de que não se tem notícia de condenação criminal desses delinqüentes que já foram pilhados na utilização de escravidão rural ou de imigrantes nas cidades, talvez fosse excesso de otimismo imaginar-se punição de empregadores que se beneficiam do trabalho urbano em condições de neo-escravidão, ou seja, naquelas práticas definidas como crime de submeter trabalhadores a condições de trabalho análogas à de escravos.
Não é o caso de se reprisar neste artigo a extensa bibliografia que analisa o "caráter seletivo" da atuação da jurisdição penal quanto às classes sociais (BARATTA, 2002), eis que tal assunto encontra-se em amplo debate nos últimos anos. De fato, já se consagrou em senso comum que raramente se punem criminosos integrantes das classes sociais dominantes, dispensando-se maiores esforços argumentativos.

Sendo assim, embora reste evidente, com a nova redação do artigo $149, \mathrm{CP}$, que agora considera crime submeter empregado a condições degradantes ou a jornadas exaustivas, como visto acima, consistiria ingenuidade supor-se que, de uma hora para outra, promotores de justiça e magistrados da justiça criminal passassem a fazer incidir o peso da repressão penal sobre empregadores (ou seus prepostos) pilhados em práticas neoescravistas. No sistema capitalista não foi para essa classe social que se edificaram as cadeias, admita-se.

Tendo por pressuposto esta última posição ultra-realista, esvaece-se o dilema enunciado $^{23}$ pois, no atual estágio da correlação de forças, materializado na ossatura material do Estado, em suas leis e em suas instituições (POULANTZAS, 1990), nulifica-se a vontade de se assegurar a

${ }^{23}$ Deve-se advogar a ampliação das hipóteses a serem consideradas como de "condições degradantes de trabalho" e de "condições de trabalho em jornadas excessivas" como caracterizadoras de "trabalho em condições análogas à de escravo", mesmo correndo o risco de banalizar tal discussão, ou, ao contrário, em homenagem a uma maior efetividade (e maiores possibilidades de punição, portanto), deveríamos nos autocensurar e restringir as hipóteses que seriam consideradas como "condição degradante" ou como "jornada excessiva"? 
proteção da lei aos direitos do trabalhador, e as condenações de empregadores pela prática de neo-escravidão ascendem ao limbo do esquecimento, espaço no qual a benevolência dominante se irmana. Por tal razão, parafraseando o movimento francês de maio de 1968, "soyons réalistes, demandons l'impossible". Sem autocensura, assuma-se como a postura mais correta a defesa de que, independentemente da classe social a que pertençam, todos aqueles flagrados em práticas pré-capitalistas de exploração do trabalho humano sejam submetidos ao competente inquérito criminal, obviamente, com todas as garantias do Estado Constitucional de Direito. Eventualmente, um ou outro empregador delinqüente será condenado, servindo de exemplo e, com isso, contribuindo para uma maior discussão pública a respeito, condição essencial para a erradicação de tais formas pré-capitalistas de relações de trabalho.

Para a consecução de tal propósito, todavia, a jurisdição criminal haverá de ser oficiada sempre e quando o juiz do trabalho, na apreciação de ações em que se verifiquem tais práticas, constate ocorrências desse teor. Sem uma tomada de consciência por parte da magistratura do trabalho nesse sentido, dificilmente tais crimes merecerão castigo por parte do Estado.

Obviamente, prescinde de provocação pela parte tal iniciativa do magistrado do Trabalho. Ex oficio, basta que o magistrado constate a possível prática do crime de neoescravidão para que, enviando cópia dos autos, comunique ao Ministério Público Estadual para que, assim o desejando, instaure a competente ação penal. Contudo, a parte, por seu advogado, em ação trabalhista também poderá tomar tal iniciativa, seja demandando ao juiz da causa, tal providência, seja providenciando as cópias e fazendo tal comunicação diretamente (embora a eficácia desta iniciativa tenda a ser significativamente menor do que a daquela).

Mas, como no livro de Dostoievski, o castigo por parte do Estado não norteia para uma única possibilidade. Para além do castigo criminal (o mero fato de ter que responder a ação penal sob tal imputação, admita-se, já se impõe como uma forma de castigo) e do castigo imposto pela consciência do delinqüente, como naquela obra-prima, ainda se conta com a possibilidade de castigo por intermédio da fixação de indenização por ato ilícito.

Como se sabe, principalmente depois da Emenda Constitucional 45, e mesmo antes dessa Emenda (RAMOS FILHO, 2005), os magistrados trabalhistas já dispunham de competência constitucional para condenar as empresas mediante indenizações por ato ilícito ${ }^{24}$, sendo assim, outra forma de "castigo", para que se continue a referência a Dostoievski, seria a condenação dos empregadores que se apropriam de trabalho em condições análogas à de escravo ou, mesmo, nas demais formas de escravidão contemporânea.

Novamente aqui o protagonismo do magistrado trabalhista se destaca como fundamental, pois um juiz desempenha papel

${ }^{24}$ Código Civil. Art. 186. Aquele que, por ação ou omissão voluntária, negligência ou imprudência violar direito e causar dano a outrem, ainda que exclusivamente moral, comete ato ilícito. Art. 187. Também comete ato ilícito o titular de um direito que, ao exercê-lo excede manifestamente os limites impostos pelo seu fim econômico ou social, pela boa-fé ou pelos bons costumes. Art. 927. Aquele que, por ato ilícito (art. 186 e 187) causar dano a outrem, fica obrigado a repará-lo. 
essencial na repressão do crime, ainda que pela reparação monetária. Sem uma implicação consciente da magistratura trabalhista na erradicação de todas as formas de escravidão contemporânea, inclusive da neo-escravidão, não se obterá o resultado pretendido, pois remanescerá uma das causas de sua ocorrência, a da expectativa de impunidade. E a punição cabível na esfera trabalhista é a reparatória, em valores tais que a indenização se plenifique de caráter pedagógico e inibitório para continuidade de tais práticas.

Mas, para que a jurisdição trabalhista atue na repressão ao crime, embora se possa advogar, com razão, que a iniciativa punitivo/ reparatória prescindiria de provocação da parte, pretende-se que a advocacia trabalhista obreira, atenta, quer em ações individuais, quer em ações coletivas, postule a condenação dos empregadores incursos naquelas condutas descritas abstratamente pela lei penal (art. 149, CP). Da mesma forma, as entidades sindicais obreiras.

Para efeitos de quantificação do valor da indenização, na ausência de outro critério objetivo, sugere-se opção pelo critério punitivo que já existiu na CLT, em seu artigo 467, antes da entrada em vigor da Lei $n .^{\circ}$ $10.272 / 2001^{25}$, qual seja, o dobro dos valores

${ }^{25}$ CLT, art. 467, redação anterior: "Em caso de rescisão do contrato de trabalho, motivada pelo empregador ou pelo empregado, e havendo controvérsia sobre parte da importância dos salários, o primeiro é obrigado a pagar a este, à data do seu comparecimento ao tribunal de trabalho, a parte incontroversa dos mesmos salários, sob pena de ser, quanto a essa parte, condenado a pagá-la em dobro". Redação atual: "Em caso de rescisão de contrato de trabalho, havendo controvérsia sobre o montante das verbas rescisórias, o empregador é obrigado a pagar ao trabalhador, à data do apurados na execução da sentença em relação às demais verbas decorrentes da condenação (portanto, dos valores que não foram pagos oportunamente, ao tempo da prestação laboral). Por tal critério, o valor da indenização específica, reparatória diante da constatação de trabalho escravo contemporâneo, guardaria relação com o montante da condenação, que espelha, em alguma medida, o montante de direitos violados naquele caso concreto. Embora se teçam críticas, por modesta a expressão monetária dele decorrente, tal critério já se avolumaria como robusto passo no sentido da erradicação dessas formas précapitalistas de relações de trabalho.

Em resumo, para que se atenue, no seio da sociedade, a expectativa da impunidade que se perpetua no meio jurídico quando se trata da defesa dos direitos do trabalhador, propõem-se duas iniciativas a se desenvolverem em harmônico propósito: (1) ofício ao Ministério Público, com cópia dos autos, para que o parquet analise a possibilidade de instauração de competente ação penal e (2) condenação dos empregadores ao pagamento de indenizações compensatórias. Tais medidas poderão contribuir significativamente para que não se impute à jurisdição trabalhista a mesma seletividade que se atribui à jurisdição penal.

\section{REFERÊNCIAS}

ABRAMOVICH, Víctor. COURTIS, Christian. Los derechos sociales como derechos exigibles. Madrid: Editorial Trotta, 2002;

comparecimento à Justiça do Trabalho, a parte incontroversa dessas verbas, sob pena de pagá-las acrescidas de cinqüenta por cento" (Redação dada pela Lei n. ${ }^{\mathbf{1 0}}$ 10.272/2001, de 05-09-2001). 
ALVES, Giovani. O novo (e precário) mundo do trabalho. Ed. Boitempo, 2000;

BASTOS, Guilherme Augusto Caputo. Trabalho escravo: uma chaga humana. In: Revista LTr, vol. 70, n. ${ }^{\circ}$ 03, março de 2006. p. 367-371.

BARATTA, Alessandro. Criminologia crítica e crítica do direito penal. Rio de Janeiro:

Revan, 2002.

BELISARIO, Luiz Guilherme. A redução de trabalhadores rurais à condição análoga à de escravo: um problema de direito penal trabalhista. São Paulo: LTr, 2005.

BRITO FILHO, José Cláudio Monteiro de. Trabalho com redução à condição análoga à de escravo: análise a partir do trabalho decente e de seu fundamento, a dignidade da pessoa humana. In: VELLOSO, Gabriel e FAVA, Marcos Neves (organizadores). Trabalho escravo contemporâneo: o desafio de superar a negação. São Paulo, LTr, 2006. p. 125 a 138.

BOLTANSKI, Luc; CHAPELLO, Ève. El nuevo espíritu del capitalismo. Madrid: Akal, 2002.

DELGADO, Maurício Godinho. Curso de direito do trabalho. 5. ed., São Paulo, LTr, 2006.

FELICIANO, Guilherme Guimarães. Do crime de redução a condição análoga à de escravo, na redação da lei $n$. 10.8032003, conforme acesso em 28/09/2008 à página http://www.trt15.jus.br/ escola_da_magistratura/Rev25Art4.pdf.

FORRESTER, Viviane. O horror econômico. São Paulo, Editora Universidade Estadual Paulista, 1997.

GONÇALVES, Luis Carlos dos Santos e CARVALHO, Ana Paula Giamarusti. Trabalho escravo e competência. In: Repertório de Jurisprudência IOB, set/2004, n. ${ }^{\circ} 17$, vol. III. p. 501-503.

JARDIM, Phillippe Gomes. Para uma crítica ao trabalho escravo contemporâneo no Brasil: dos direitos humanos à neo-escravidão. Sevilha: tesina apresentada como requisito para conclusão do Master em Derechos Humanos y Desarollo, Universidad Pablo de Olavide, 2008, sob a orientação do autor.
HERRERA FLORES, Joaquin. La reinvención de los Derechos Humanos. Sevilla:

Ed. Atapasueños, 2008.

MARASCHIN, Cláudio. O trabalho escravo no Brasil contemporâneo (uma análise jurídicosocial). In: CD Rom Júris Síntese Milenium.

MÉDA, Dominique. Le Travail. Paris: PUF - Presses Universitaires de France, 2004.

MENDES, Almara Nogueira. Nova forma de escravidão urbana: trabalho de imigrantes.

Revista do Ministério Público do Trabalho,

São Paulo, Ano XIII, n.26, p.68, 2003

NEGRISOLI, Fabiano. O salário degradante e a jornada exaustiva configuradores do trabalho escravo, inédito, 2008.

NEVES, Robinson. Trabalho escravo: modificação do tipo penal. In: CD ROM - Juris Sintese Millennium.

PEREIRA PINTO, Airton. Direito do trabalho, direitos humanos sociais e a constituição federal. São Paulo, LTr, 2006.

PIOVESAN, Flávia. Trabalho escravo e degradantes como forma de violação aos direitos humanos. In: VELLOSO, Gabriel e FAVA, Marcos Neves (organizadores). Trabalho escravo contemporâneo: o desafio de superar a negação. São Paulo, LTr, 2006. p. 151 a 165.

PISARELLO, Gerardo. Los derechos sociales y sus garantías. Elementos para una reconstrucción. Madrid: Editorial Trotta, 2007.

POULANTZAS, Nicos. Estado, poder e socialismo. São Paulo: Graal, 1990.

PRONER, Carol. Propriedade intelectual e direitos humanos. Sistema Internacional de Patentes e Direito ao Desenvolvimento.

Porto Alegre: Fabris, 2007.

RAMOS FILHO, Wilson. Direito, economia, democracia e o sequiestro da subjetividade dos juslaboralistas. Revista do Tribunal Regional do Trabalho da $9^{a}$ Região. Curitiba, páginas 147 a 166, 2001. 
RAMOS FILHO, Wilson. (Org.). Constituição e Competência Material da Justiça do Trabalho. Curitiba: Gênesis Editora, 2005.

RAMOS FILHO, Wilson. Delinqüência

Patronal, Repressão e Reparação. Prelo, 2008.

SANTA CATARINA, Daniele Correa. Tráfico de mulheres brasileiras para exploração sexual na Espanha. Sevilha: tesina apresentada como requisito para conclusão do Master em Derechos Humanos y Desarollo, Universidad Pablo de Olavide, 2008, sob a orientação do autor.
SARLET, Ingo Wolfgang. Os direitos fundamentais sociais na constituição de 1988. Disponível em <http:www.direitopublico.com. br>, acessado em 07 de novembro de 2006.

SIMM, Zeno. $O$ acosso psíquico no ambiente de trabalho. São Paulo, LTr, 2008.

SIQUEIRA, Marli Aparecida da Silva. Trabalho escravo e trabalho forçado. In: CD ROM Júris Síntese Milenium.

SÜSSEKIND, Arnaldo et alli. Instituições de direito do trabalho. 19.ed. São Paulo: LTr, 2000. 